\title{
Central Nervous System Circuitries Underlying Two Types of Peripheral Autonomic Nervous System Disorders
}

\author{
Fuad Lechin* and Bertha van der Dijs
}

\author{
Departments of Neurophysiology, Neurochemistry, Neuropharmacology and Neuroimmunology, Instituto de Medicina \\ Experimental, Faculty of Medicine, Universidad Central de Venezuela, Caracas, Venezuela
}

\begin{abstract}
The assessment of circulating neurotransmitters: noradrenaline, adrenaline, dopamine, platelet serotonin, plasma serotonin and plasma tryptophan before and after many types of stressor agents and neuropharmacological drugs carried out over the last thirty years allowed us to accumulate information dealing with the central nervous system (CNS) versus the peripheral autonomic nervous system (ANS) interactions in healthy as well as diseased mammals. Furthermore, the accurate knowledge about the CNS circuitry disorders which underlie both the CNS and peripheral clinical syndromes, has allowed us to prescribe successful neuropharmacological therapeutical strategies for many types of illnesses. In addition, the demonstration that the clinical improvement was always paralleled by the normalization of the neurochemical, hormonal, immunological and clinical profiles affords strong support to our point of view. According to all the above, the authors postulate the existence of two types of diseases: type A and Type N, which are underlain by two opposite CNS + ANS disorders. Type A diseases should be associated with the "uncoping stress" syndrome and are underlain by hyperactivity of the adrenocortical glands plus the CNS disorder characterized by the predominance of the $\mathrm{C} 1$ (adrenergic) + $\mathrm{DR}$ (serotonergic) axis over the A5 (noradrenergic) + MR(serotonergic) binomial, whereas the type $\mathrm{N}$ diseases depends on the opposite profile: "endogenous depression" syndrome. Finally, we quoted exhaustive evidence showing that the well known fading of both the A6(noradrenergic) + C1(adrenergic) CNS nuclei activity occurring during aging is responsible for the ANS + CNS disorder which is similar to that underlying psychosis, Alzheimer, post-traumatic stress disorder and deficit-attention hyperactive disorder.
\end{abstract}

\section{INTRODUCTION}

We have assessed the peripheral autonomic nervous system (ANS) in more than 30, 000 healthy and diseased subjects, throughout the last 30 years. Circulating neurotransmitters [noradrenaline (NA), adrenaline (Ad), dopamine (DA), plasma free serotonin (f-5-HT), platelet serotonin (p5-HT) and tryptophan (trp)], blood pressure (BP), heart rate (HR), plasma glucose, plasma insulin, plasma cortisol, plasma prolactin and other hormones have been also investigated before and after different types of stressor such as orthostasis, exercise [1-5], and oral glucose tolerance test [6-8]. We have also investigated the effects induced by different types of drugs: clonidine [9-11], sibutramine [12], buspirone [13], tianeptine [14], arginine [15], doxepin [8], dexamethasone $[16,17]$ on the circulating neurotransmitters of both normal and diseased subjects.

The neurotransmitters have also been investigated during sleep periods $[18,19]$ in normal and diseased subjects. Finally, the above tests have been carried out during both relapsing and remission periods. The information derived from that research work has allowed us to understand the pathophysiological mechanisms which underlie most type of diseases: gastrointestinal, cardiovascular, endocrinological, neurological, psychiatric and others; and in addition, to be the first to demonstrate the neuroautonomic profiles which

*Address correspondence to this author at the Departments of Neurophysiology, Neurochemistry, Neuropharmacology and Neuroimmunology, Instituto de Medicina Experimental, Faculty of Medicine, Universidad Central de Venezuela, Caracas, Venezuela; E-mail: flechin@movistar.net.ve underlie psychosis [20-23], endogenous depression [4, 24], hyperinsulinism [8, 24-31], biliary dyskinesia [32-34], ulcerative colitis [35], infertility [26,36], duodenal ulcer and gastritis [37, 38], irritable bowel syndrome [39-43], Crohn's diseases [44, 45], pancreatitis [45-48], essential hypertension $[6,49,50]$, thrombocytopenic purpura [51], polycythemia vera [52], myasthenia gravis [53], reactive hypoglycemia [8], cardiovascular and pulmonary disorders [53-60], bronchial asthma [61-64], neurological disorders [65, 66], and others. In addition, we demonstrated that the enhanced plasma levels of Ad were associated with both cancer progression and natural killer cells hypoactivity [67-69]. Furthermore, the systematic assessment of the neurochemical plus immunological parameters allowed us to demonstrate that $\mathrm{TH}-1$ and TH-2 autoimmune diseases are underlain by neural sympathetic and adrenal sympathetic predominance, respectively [67]. Finally, in the present review article we will refer to the adequate differentiation of both types of syndromes, which allow successfully treatment with neuropharmacological manipulations of drugs addressed to revert the CNS + ANS disorders.

\section{ANATOMICAL EVIDENCE}

The pontomedullary A5 noradrenergic (NA) nucleus is responsible for the activity of the neural sympathetic nervous system [70-72]. This nucleus sends excitatory axons to the lumbar sympathetic acetylcholinergic $(\mathrm{ACh})$ pre-ganglionic neurons located at the spinal intermedio lateral segment [7375]. Axons of these neurons innervate the somatodendritic area of the NA neurons located at the sympathetic ganglia, which are crowded by nicotinic (excitatory) receptors [76]. 
Noradrenergic axons of these neurons integrate sympathetic nerves, which release $80-90 \%$ of NA plus $10-20 \%$ of DA [77]. Conversely, the medullary $\mathrm{C} 1$ adrenergic (Ad) nuclei send glutamatergic axons to the spinal intermedio lateral ACh neurons located at the thoracic segment which sends excitatory axons to the adrenal glands that secrets $80 \%$ Ad + $10 \% \mathrm{NA}+10 \%$ DA, approximately [70-72, 78-80], which are crowded by excitatory nicotinic receptors [81]. Moreover, the $\mathrm{A} 5(\mathrm{NA})$ and the $\mathrm{C} 1(\mathrm{Ad})$ nuclei interchange inhibitory axons [74, 76, 82, 83]. Noradrenaline and adrenaline released from both types of axons act at postsynaptic inhibitory alpha-2 receptors [84] hence, both peripheral sympathetic branches can modulate each other [85, 86]. Besides, those catecholaminergic nuclei send inhibitory axons to the A6(NA) or locus coeruleus pontine nucleus, at which level secrete noradrenaline and adrenaline, respectively. These catecholamines released at the A6(NA) nucleus exert their inhibitory effects by acting at alpha-2 receptors which crowd this nucleus. Furthermore, A6(NA) neurons send direct inhibitory axons to the A5(NA) and modulatory (polysynaptic) drives to the $\mathrm{C} 1$ (Ad) nuclei [73, 76, 77, 87-93]. However, A6(NA) neurons may also be excited by glutamic acid [89] as well as by $\mathrm{ACh}$ axons which arise from the brain cortex and the pedunculo pontine nucleus (PPN), respectively [94, 95]. The former excitatory drive act at the glycine component of the NMDA receptors, whereas the ACh axons act at the muscarinic receptors located at the A6(NA) nucleus [65]. Finally, ACh axons which arise from the medullary vagal complex are also able to excite the A6(NA) neurons [65, 67], during acute parasympathetic rebounds that provoke abrupt inhibitory responses from the A6(NA) axons addressed to restore the ANS acute unbalance episode. This effect is mediated by the release of noradrenaline from the A6 axons at the medullary nucleus tractus solitarii (ACh) [96-98].

\section{PHYSIOLOGICAL EVIDENCE}

The A5(NA) and the $\mathrm{C} 1(\mathrm{Ad})$ nuclei innervate subcortical structures [93], whereas the A6(NA) innervates both the brain cortex and subcortical areas [99]. Hence, this latter nucleus does not display primary (direct) effects on the ANS physiological mechanisms. This phenomenon is consistent with others showing that the number of neurons of the A5(NA) and C1(Ad) nuclei is completed by birth [93, 100103] whereas the number of A6(NA) neurons do not reach totality until adultness [104-114]. Furthermore, these neurons fade gradually with aging [104, 107, 115]. This fading is paralleled by the underactivity of the $\mathrm{C} 1(\mathrm{Ad})$ nuclei in such a way that aging is always accompanied by the progressive predominance of the A5(NA)-neural sympathetic activity. These findings are also consistent with facts showing that most psychiatric disturbances - psychosis $[67,105,116$, 117], attention-deficit hyperactive disorder [65], posttraumatic-stress-disorder [118, 119], and Alzheimer disease [120] - are underlain by the underactivity of the A6(NA) plus the predominance of the A5(NA) neurons that are responsible for the peripheral neural sympathetic system [121-127]. This latter explains the raised NA/Ad ratio always registered in these patients. Finally, we have demonstrated that this neurochemical profile is reversible in endogenous depression patients but not in the other named disturbances [67]. According to all the above, the therapeutical strategy pretending to improve these syndromes should be addressed to revert the A5(NA) over A6(NA) predominance. In addition to that, it should be expected that the minimization of the A5(NA) activity triggered by this therapy would be paralleled by the disinhibition of the $\mathrm{C} 1(\mathrm{Ad})$ and the A6(NA) activities [124].

Other physiological evidence showed that the two branches of the peripheral ANS: neural and adrenal sympathetic, are able to antagonize the parasympathetic activity which depends on the release of ACh from these nerves, at visceral targets. This neurotransmitter is not detectable at the peripheral blood because it is fastly destroyed by the acetyl cholinesterase enzyme. Moreover, this neurotransmitter is uptaked by platelets [2, 125]. However, ACh released from parasympathetic nerves is able to act at the nicotinic and muscarinic receptors located at the visceral and muscle levels. Furthermore, parasympathetic nerves interact with sympathetic nerves throughout modulatory rather than a "black vs. white" antagonism [126-129]. Thus, the assessment of the peripheral circulating ACh levels would not afford a useful tool for the understanding of the pathophysiological and/or clinical disorders. Besides, a close cooperation between the peripheral ACh and serotonin neurotransmitters has been demonstrated $[2,125,130,131]$. This factor affords additional complexity to the management of this circulating neurotransmitter as a useful tool to the understanding of the peripheral ANS mechanisms, as is the case of circulating catecholamines and indolamines.

The circulating serotonin ( $\mathrm{p}-5-\mathrm{HT}$ plus $\mathrm{f}-5-\mathrm{HT}$ ) is released from the enterochromaffin cells located at the small bowel mucosa. Parasympathetic nerves exert an excitatory effect at these cells whereas sympathetic nerves display the opposite activity. Serotonin released to the blood during postprandial periods is partially uptaked by the liver, the lungs and platelets (p-5-HT). However, a small fraction remains free in the plasma ( $\mathrm{f}-5-\mathrm{HT})$. This plasma serotonin is able to excite the area postrema located at the medullary level (outside the blood brain barrier). This parasympathetic nucleus initiates a cascade of excitatory drive at the CNS which redounds in the additional increase of the enterochromaffin cells activity. Thus, a positive feedback mechanism is triggered. Exacerbation of this peripheral + CNS interaction underlies the pathophysiology of the Bezold Jarisch syndrome [132-135]. This disturbance is successfully treated throughout an adequate neuropharmacological therapy, addressed to enhance the neural sympathetic activity which annuls parasympathetic overactivity $[12,14,52,54,136-$ 139].

\section{PATHOPHYSIOLOGICAL EVIDENCE}

The assessment of both circulating neurotransmitters and immunological parameters has demonstrated that almost all diseases are underlain by neuroautonomic plus immunological disorders depending on the neurosympathetic or adrenal sympathetic predominance. The former group is frequently paralleled by the TH-1 immunological profile, whereas the latter is associated with the TH-2 immunological predominance. This adrenal sympathetic group presents with abrupt oscillations between the adrenal sympathetic versus parasympathetic predominance whereas patients affected by neural sympathetic hyperactivity present a rigid profile which shows few and slight alternancy with the parasympathetic ANS profile. These phenomena find explanation in facts 
showing that whereas the $\mathrm{C} 1(\mathrm{Ad})$ medullary nuclei are heavily interconnected with the ACh (medullary) structures, the A5(NA) pontomedullary nucleus sends inhibitory axons to but does not receive from the medullary vagal structures $[65$, $67,140,141]$. Furthermore, the flexibility of the Ad vs. ACh medullary interaction is extended to the peripheral adrenergic vs. parasympathetic branches [67, 142]. These physiological plus pathophysiological interactions are monitored by the area postrema. This ACh structure is located at the floor of the IV ventricle and in addition, is not protected by the blood brain barrier, in such a way that the external face is bathed by the blood whereas the internal face interchange axons with other medullary nuclei. Serotonergic 5-HT-3 receptors are excited by the free plasma serotonin (f-5-HT), which is released from the enterochromaffin cells under parasympathetic excitatory drive [131, 143-145]. It functions as an alarm timber which sends signals to the $\mathrm{C} 1(\mathrm{Ad})$ nuclei. Thus all peripheral parasympathetic overexcitation is fastly annulled by the adrenal glands secretion of adrenaline. In addition, the overexcited $\mathrm{C} 1(\mathrm{Ad})$ nuclei send inhibitory axons to the A5(NA) neurons $[146,147]$, thus, the neural sympathetic activity is also annulled in these acute circumstances. This abrupt adrenergic response, registered during acute stress periods is not registered in elderly people because of the hyporesponsiveness of their adrenal cortical glands. These facts explain the different neurohormonal stress profiles registered in young and elderly mammals [3, $16,17,148]$.

In summary, we should understand that the acute stress in young mammals is underlain by raised catecholamines plasma levels + low NA/Ad ratio + raised cortisol plasma levels, whereas in elderly mammals, the acute stress is underlain by moderately raised catecholamines + normal or high NA/Ad ratio + moderately raised cortisol in the plasma, however, it is important to know that both basal noradrenaline and cortisol are permanently raised in elderly people when tested versus young people. The A5(NA) over the $\mathrm{C} 1(\mathrm{Ad})$ predominance registered in the former explain the above catecholamines profiles, whereas the higher cortisol plasma levels, registered in elderly people depends on the predominance of the median raphe (MR) over the dorsal raphe (DR) serotonergic neurons registered during aging. This MR(5-HT) over DR(5-HT) predominance parallels the A5(NA) over C1(Ad) unbalance [136]. With respect to this, it should be known that the C1(Ad) and DR(5-HT) activities are positively correlated thus, any enhancement of activity of the first is followed by the excitation of the second, because both nuclei interchange excitatory axons. Furthermore, the fading of these two nuclei, registered during elderly fits well with all the above. Moreover, the fact that basal cortisol plasma levels are raised during aging finds explanation in other facts showing that serotonin released at the hypothalamic level is released from the MR(5-HT) rather than the DR(5-HT) axons [136]. The former axons trigger the release of serotonin as a continuous but not intermittent flowing which provokes down regulation of the hypothalamic cortisol receptors because of the sustained basal release of this hormone [136]. This phenomenon is consistent with the nonsuppression of plasma cortisol during the dexamethasone suppression challenge registered in elderly people [17]. This disorder is similar to that registered in endogenous depressed patients [10]. Besides, it should be remembered that both endogenous depressed and elderly people share the same neuroendocrine and neuroautonomic profiles as well as psychotic, post-traumatic stress and attention-deficit hyperactive disorders. All of them present with neural sympathetic over adrenal sympathetic predominance [67]. These pathophysiological disorders are paralleled by the same neurocircuitry disorder: $\mathrm{A} 5(\mathrm{NA})$ predominance over the $\mathrm{C} 1(\mathrm{Ad})+\mathrm{A} 6(\mathrm{NA})$ and MR(5-HT) over DR(5-HT) predominance [65].

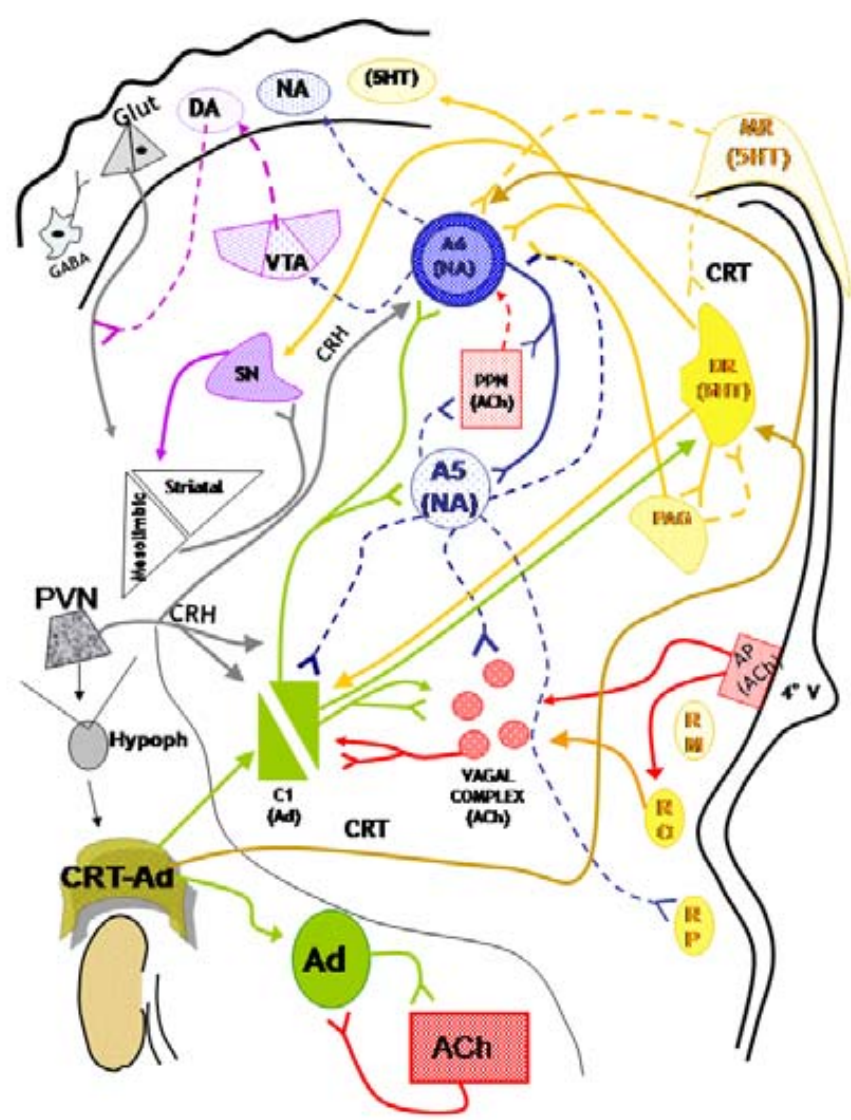

Fig. (1). Adrenal sympathetic activity. This peripheral branch of the autonomic nervous system depends on the secretion of catecholamines by the adrenal gland $[80 \%$ of adrenaline (Ad) + $20 \%$ of noradrenaline (NA) $+10 \%$ of dopamine (DA)]. These glands receive excitatory axons from the thoracic presynaptic (ACh) neurons. These ACh-neurons depends on the excitatory drives arising from the $\mathrm{C} 1$-Ad medullary nuclei, which in addition send inhibitory axons to both the A5(NA) and the A6(NA) nuclei. Furthermore, these subjects present also, raised levels of plasma cortisol (CRT), which depends of the DR-5HT axons. This serotonergic nucleus interchanges excitatory drives with the C1(Ad) nuclei. Finally, both DR(5-HT) and C1(Ad) axons excite the hypothalamic paraventricular nucleus. Evenmore, CRT crosses the blood brain barrier and excites the DR(5-HT). This positive feedback explains the raised levels of circulating adrenaline and CRT, always registered in these patients. The above anatomical + physiological + pathophysiological mechanisms are reverted by administration of NA uptake inhibitors like desipramine. Finally, the raised levels of Ad and CRT in the plasma are consistent with the bulk of clinical syndromes underlain by the uncoping stress syndrome [67]. 


\section{THERAPEUTICAL EVIDENCE SUPPORTING THE POSTULATION THAT THERE EXIST TWO TYPES OF DISEASES: NEURAL SYMPATHETIC (N) AND ADRENAL SYMPATHETIC (A)}

\section{Type A Diseases (See Fig. 1)}

Considering that these diseases are underlain by the adrenal sympathetic overactivity (uncoping stress profile), the therapy should be addressed to enhance neural sympathetic activity; thus the treatment includes the administration of a noradrenaline-uptake inhibitor like desipramine [149-151] in order to enhance the activity of the A5(NA) neurons which are inhibited by both the $\mathrm{C} 1$ (Ad) and the A6(NA) axons in these patients [152]. These latter nuclei are hyper-excited by the over-release of corticotrophin releasing hormone (CRH) from hypothalamic axons. This phenomenon explains why yohimbine (an alpha-2 antagonist) should be added to desipramine. This alpha- 2 antagonist would excite the firing activity of the hypoactive A5(NA) rather than the hyperactive $\mathrm{C} 1$ (Ad) and/or A6(NA) neurons [153]. Obviously, the administration of yohimbine would act neither at the A6(NA) neurons [154], nor at the C1(Ad) or the DR(5-HT) neurons because all three nuclei are hyper-excited by the $\mathrm{CRH}$ released from paraventricular hypothalamic terminals. According to the above, the recovery of the A5(NA) neurons would reduce the $\mathrm{C} 1(\mathrm{Ad})+\mathrm{A} 6(\mathrm{NA})$ over-activity, responsible for the hypersecretion of adrenaline plus cortisol [136, 155-159].

Moreover, the DR(5-HT) nucleus interchanges excitatory axons with the $\mathrm{C} 1(\mathrm{Ad})$ neurons and sends inhibitory axons to the A6(NA) nucleus [88, 160]. In addition, plasma cortisol crosses the blood brain barrier and excites cortisol-receptors located at the DR(5-HT) neurons [67]. Furthermore, serotonin released from the DR(5-HT) axons at the hypothalamic level excites the CRH + ACTH + cortisol cascade [161, 162] that underlies the hormonal branch of "uncoping stress" syndrome, which cooperates with the above explained positive feedback. Summarizing, the inhibition of the hyperactive C1(Ad) neurons would disinhibit the A5(NA) nucleus and in addition, will reduce its excitatory drives to the $\mathrm{DR}(5 \mathrm{HT})$ nucleus, which would redound in the disinhibition of the A6(NA) neurons [136, 163, 164].

With respect to all the above, it should be known that the raised adrenaline plasma levels registered during the uncoping stress periods are responsible for the TH-2 immunological profile, which always parallels this syndrome that underlies both infectious and malignant diseases during relapsing periods. This neuroimmunological disorder depends on the ability by the raised levels of adrenaline to interfere with the natural killer $(\mathrm{NK})$ cells cytotoxicity against the malignant cells. This phenomenon fits well with the successful therapeutical effects obtained in advanced cancer patients with neuropharmacological manipulations addressed to reduce plasma Ad levels [44, 65, 67, 68, 165-168].

Besides, it is necessary to normalize the sleep disorder which is always present at these circumstances. This target is reached by the administration of clonidine $(0.15 \mathrm{mg})$ plus doxepin $(25 \mathrm{mg}$ ) or imipramine $(25 \mathrm{mg})$ or clomipramine $(25 \mathrm{mg})$ at nocturnal period. The former drug (an alpha-2 agonist) would attenuate the overactivity of the A5(NA) + A6(NA) + DR(5-HT) nuclei triggered by the diurnal pre- scription (all of them are crowded by inhibitory alpha- 2 receptors) whereas the tricyclic drugs would allow the slow plus progressive fading rather than the sudden fall of the above mentioned A6(NA) + DR(5-HT) nuclei [18, 169-172]. These tricyclic drugs are both NA- and 5-HT-uptake inhibitors thus, they would interfere with the abrupt fall of the firing activity of the NA plus 5HT neurons, allowing a gradual and progressive fading of this binomial system [173]. This neuropharmacological manipulation is necessary to elongate the slow wave sleep (SWS) and avoid the short-rapid eye movement (REM) latency always present in both stressed and endogenous depressed patients $[174,175]$.

\section{Type N Diseases (See Fig. 2)}

Taking into account that these diseases are underlain by neural sympathetic predominance plus reduced adrenal sympathetic activity: $\mathrm{C} 1(\mathrm{Ad})+\mathrm{A} 6(\mathrm{NA})+\mathrm{DR}(5-\mathrm{HT})$, our therapeutical strategy is addressed to revert this neurochemical profile. With respect to this, we prescribe the following treatment: an noradrenaline-uptake inhibitor like desipramine + an alpha-2 agonist such as clonidine, plus physostigmine or rivastigmine (ACh inhibitors, which excite the A6(NA) and the $\mathrm{C} 1(\mathrm{Ad})$ nuclei but not the A5(NA) neurons) [176178], plus olanzapine or any other similar drug before breakfast and lunch. In addition, we add doxepin or clomipramine or imipramine before supper and mirtazapine (an alpha- $2+$ 5HT-2 antagonist) before bed. We will explain the rationality of this therapeutical approach.

Clonidine should inhibit the overactive A5(NA) but not the hypoactive $\mathrm{C} 1(\mathrm{Ad})+\mathrm{A} 6(\mathrm{NA})$ neurons thus, desipramine would act at the latter rather than at the former NA nucleus $[80,84,179-182]$. The nocturnal administration of mirtazapine would excite the release of NA + 5-HT from the A6(NA) $+\mathrm{DR}(5-\mathrm{HT})$ neurons, respectively, whereas the above mentioned tricyclic (doxepin, imipramine or clomipramine) would facilitate the prolongation of the simultaneous release of NA + 5-HT triggered by mirtazapine. This therapeutical strategy allows the prolongation of the SWS and avoids the short-REM latency. With respect to the above, it should be known that our sleep laboratory demonstrated $[18,24]$ that the prolongation of the SWS depends on the slow and progressive fading of the noradrenaline circulating levels and that the REM sleep appearance is paralleled by the maximal fall of it. These findings are consistent with others showing that this last sleep period is characterized by the absolute disappearance of the firing rate of both A6(NA) + DR(5-HT) neurons [82, 175, 183]. This explains why all patients affected by the obstructive sleep apnea syndrome present with raised NA/Ad plasma ratio (neural sympathetic overactivity) [24, 174, 183-187]. The above phenomena are consistent with others showing that A6(NA) and A5(NA) axons display a black vs. white antagonism at the upper pharynx and respiratory areas; excitation by the former triggers the opening of it, whereas the latter provokes the closure of this segment [128, 183-187].

\section{NEURAL SYMPATHETIC OR ADRENAL SYMPA- THETIC VS. PARASYMPATHETIC INTERACTIONS}

Neural sympathetic activity depends on the A5(NA) neurons which send excitatory (glutamatergic) axons to the lumbar sympathetic (lateral) spinal (ACh) neurons. Axons of these latter integrate the sympathetic pre-ganglionic nerves 
which synapse at these ganglia. Acetylcholine released from these axons excites post-synaptic nicotine receptors located at these (NA) neurons [76, 127]. Axons of these NA neurons integrate the sympathetic nerves which act at all peripheral and visceral targets. In addition, sympathetic nerves are crowded by muscarinic excitatory plus DA-2 inhibitory receptors in such a way that circulating acetylcholine released from parasympathetic nerves is able to enhance neural sympathetic activity at visceral levels [87, 101, 164, 188-191]. This ACh + NA interaction allows the fast excitation of the neural sympathetic branch. In addition to the above, sympathetic nerves innervate and inhibit the adrenal glands secretion by acting at alpha- 2 receptors located at this level [128, 192].

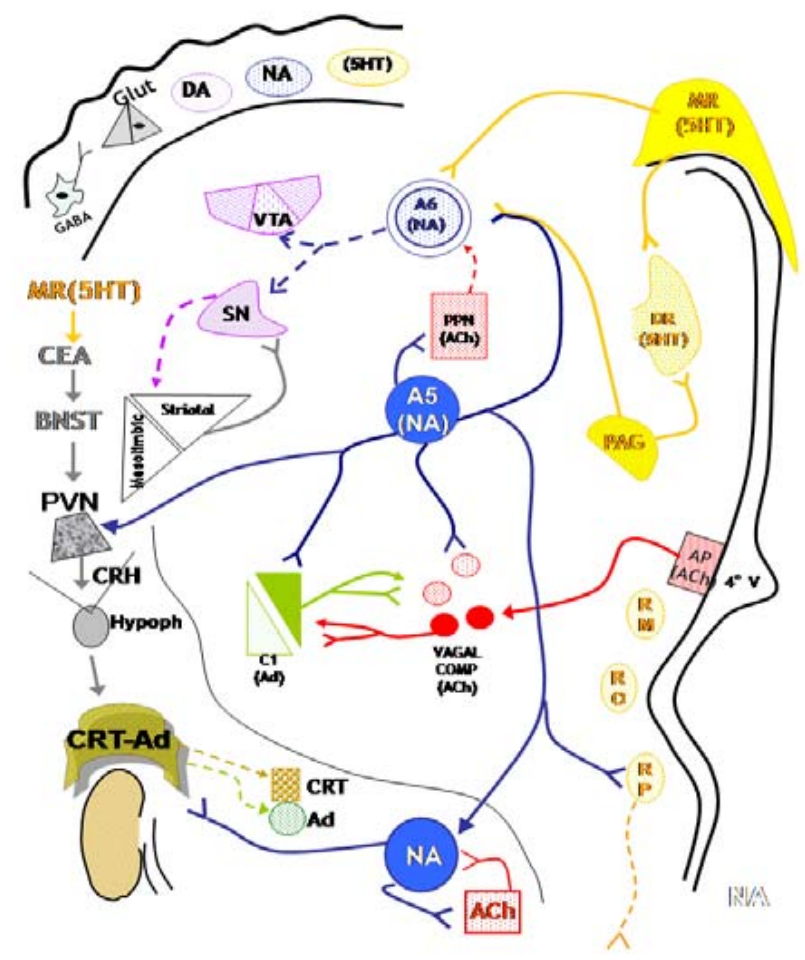

Fig. (2). Neural sympathetic activity. Neural sympathetic activity depends on the sympathetic nerves release of noradrenaline (NA) $(90 \%)+$ dopamine (DA) $(10 \%)$. This branch of the peripheral autonomic nervous system (ANS) is positively correlated with activity of the ponto-medullary A5(NA) neurons, which excite the spinal sympathetic neurons and inhibit the $\mathrm{C} 1(\mathrm{Ad})$ medullary nuclei (responsible for the adrenal glands secretion). In addition, A5(NA) axons inhibit the medullary vagal complex. The absence of $\mathrm{C} 1(\mathrm{Ad})$ activity redounds in the hypoactivity of the DR(5-HT) neurons. Serotonin released from these axons is the most important factor which initiates and prolongs the corticotrophin releasing hormone $(\mathrm{CRH})$ secretion by the paraventricular nucleus (PVN) at the hypothalamus. The minimization of this factor is consistent with the moderated rise of plasma cortisol (CRT), always registered during neural sympathetic overactivity. In addition to the above, it has been demonstrated that sympathetic nerves inhibit the adrenal glands secretion, directly, by acting at alpha- 2 receptors located at these glands. This is consistent with the raised NA/Ad plasma ratio registered in these patients. Furthermore, overactivity of the sympathetic nerves provokes vascular, bronchial, sphincteral (gastrointestinal, urinary) contraction always present in this circumstance [67].
Adrenal sympathetic activity depends on the $\mathrm{C} 1(\mathrm{Ad})$ medullary neurons which send glutamatergic axons to the thoracic sympathetic (lateral) spinal (ACh) neurons [87]. Axons of these neurons innervate the adrenal glands, which are crowded by excitatory nicotine receptors [81]. Adrenaline released from the adrenal glands to the blood stream reaches visceral areas at which level display opposite effects to those triggered by the sympathetic nerves [193]. These effects are mediated by beta- 2 receptors, however some areas are crowded by alpha-2 receptors but not by the former [194]. Excitation of alpha-2 receptors by circulating adrenaline provokes cooperator effects with the noradrenaline released from sympathetic nerves. In addition, these nerves are also provided with excitatory alpha-2 receptors [193]. According to all the above, this complex peripheral ANS interaction between the two branches of the peripheral ANS explains the severe pathophysiological disorders arising from the deficit of the adrenal glands secretion, at which circumstances the crosstalk between three factors (neural sympathetic, adrenal sympathetic and parasympathetic) is reduced to two of them [190-196]. Other factors, like the peripheral serotonergic system cooperates with the parasympathetic activity, which triggers the release of 5-HT from the intestinal source and in addition, this latter display an excitatory effect at the area postrema medullary nucleus responsible for the enhancement of the parasympathetic activity. This positive cholinergic plus serotonergic feedback is observed during the called serotonergic syndrome registered in patients affected by the carcinoid syndrome [131-133, 143].

\section{CENTRAL NERVOUS SYSTEM \& PERIPHERAL AUTONOMIC NERVOUS SYSTEM PROFILES WHICH UNDERLIE AGING}

The underactivity of the adrenal sympathetic system registered during aging converts the trinomial physiological structure which includes neural sympathetic, adrenal sympathetic and parasympathetic branches of the peripheral ANS in a binomial anatomical + physiological "black and white" circuitry. This phenomenon is responsible for the lack of the normal flexibility and compliance which allows the mitigation of the responses to stressor stimuli [108, 194-198].

The A6(NA) and the A5(NA) as well as the C1(Ad) nuclei are excited during acute stress, in such a way that the two sympathetic branches of the ANS might be able to respond in association or dissociation [85]. This compliance allows the attenuation of the stressors effects and avoids the abrupt appearance of the exhaustion periods (uncoping stress). Evenmore, the repetition of controllable stressing periods allows the adaptation to them (coping stress). This physiological capability fades progressively with aging [199201], because of the progressive minimization of the adrenal glands activity. This peripheral phenomenon finds explanation in the well known reduction of the number of the A6(NA) neurons, which integrate the locus coeruleus pontine nucleus, throughout aging [104]. With respect to the above, it should be remembered that this nucleus interchanges inhibitory axons with the A5(NA) nucleus and in addition sends and receives modulatory axons to and from the C1(Ad) medullary nuclei, which in turn, innervate the A5(NA), at which level provokes inhibitory responses [67]. 


\section{CONCLUSIONS}

The peripheral ANS is modulated by three CNS circuits located at the pontomedullary level: 1) the $\mathrm{Cl}(\mathrm{Ad})$ vs. the vagal complex; 2) the pontomedullary $\mathrm{A} 5(\mathrm{NA})+\mathrm{C} 1(\mathrm{Ad})+$ the vagal complex, and 3) the A6(NA) nucleus which interchanges inhibitory axons with the A5(NA) + $\mathrm{C} 1(\mathrm{Ad})$ but that is also able to excite or inhibit the latter. The adequate understanding of the above crosstalk is absolutely necessary to treat the ANS disorder underlin diseases. According with this point of view, we postulate the existence of two types of diseases: 1) Type $\mathrm{N}$ [underlain by hypoactivity of the A6(NA) + C1(Ad) nuclei plus hyperactivity of the A5(NA) nucleus] which includes: aging, psychosis, endogenous depression, post-traumatic stress disorder, deficit-attention hyperactivity disorder, essential hypertension, hyperinsulinism, multiple sclerosis, myasthenia gravis, and others. This ANS unbalance is associated to $\mathrm{TH}-1$ immunological predominance. 2) Type A diseases underlain by hyperactivity of the $\mathrm{C} 1(\mathrm{Ad})+\mathrm{DR}(5-\mathrm{HT})$ nuclei plus hypoactivity of the A5(NA) nucleus (uncoping stress disorder). This ANS unbalance is associated to TH-2 immunological predominance.

\section{REFERENCES}

[1] Lechin F, van der Dijs B, Lechin ME, et al. Plasma neurotransmitters, blood pressure and heart rate during supine-resting, orthostasis, and moderate exercise conditions in two types of hypertensive patients. Res Commun Biol Psychol Psychiatry 1997; 22: 111-45.

[2] Lechin F, van der Dijs B, Orozco B, et al. Plasma neurotransmitters, blood pressure and heart rate during supine-resting, orthostasis and moderate exercise stress test in healthy humans before and after parasympathetic blockade with atropine. Res Commun Biol Psychol Psychiatry 1996; 21: 55-72.

[3] Lechin F, van der Dijs B, Orozco B, et al. Plasma neurotransmitters, blood pressure and heart during supine-resting, orthostasis and moderate exercise in severely ill patients: A model of failing to cope with stress. Psychother Psychosom 1996; 65: 129-36.

[4] Lechin F, van der Dijs B, Orozco B, et al. Plasma neurotransmitters, blood pressure and heart rate during supine-resting, orthostasis and moderate exercise conditions in major depressed patients. Biol Psychiatry 1995; 38: 166-73.

[5] Lechin F, van der Dijs B, Orozco B, et al. Plasma neurotransmitters, blood pressure and heart rate during supine-resting, orthostasis and moderate exercise in dysthymic depressed patients. Biol Psychiatry $1995 ; 37: 884-91$.

[6] Lechin F, van der Dijs B, Lechin M, et al. Plasma neurotransmitters throughout an oral glucose tolerance test in essential hypertension. Clin Exp Hypertension 1993; 15: 209-40.

[7] Lechin F, van der Dijs B, Lechin M, et al. Effects of an oral glucose load on plasma neurotransmitters in humans: Involvement of REM sleep? Neuropsychobiology 1992; 26: 4-11.

[8] Lechin F, van der Dijs B, Lechin A, et al. Doxepin therapy for postprandial symptomatic hypoglycemic patients neurochemical, hormonal and metabolic disturbances. Clin Sci 1991; 80: 373-84.

[9] Lechin F, van der Dijs B, Jakubowicz D, et al. Role of stress in the exacerbation of chronic illness. Effects of clonidine administration on blood pressure, nor-epinephrine, cortisol, growth hormone and prolactin plasma levels. Psychoneuroendocrinology 1987; 12: 11729.

[10] Lechin F, van der Dijs B, Jakubowicz D, et al. Effects of clonidine on blood pressure, noradrenaline, cortisol, growth hormone, and prolactin plasma levels in high and low intestinal tone depressed patients. Neuroendocrinology 1985; 41: 156-162.

[11] Lechin F, van der Dijs B, Jakubowicz D, et al. Effects of clonidine on blood pressure, noradrenaline, cortisol, growth hormone and prolactin plasma levels in low and high intestinal tone subjects. Neuroendocrinology 1985; 40: 253-61.

[12] Lechin F, van der Dijs B, Hernandez G, Orozco B, Rodriguez S, Baez S. Effects of sibutramine on circulating neurotransmitters in healthy subjects. Neurotoxicology 2006; 27: 184-91.

[13] Lechin F, van der Dijs B, Jara H, et al. Plasma neurotransmitter profiles of anxiety, phobia and panic disorder patients. Acute and chronic effects of buspirone. Res Commun Biol Psychol Psychiatry 1997; 22: 95-110.

[14] Lechin F, van der Dijs B, Hernandez G, Orozco B, Rodriguez S, Baez S. Acute effects of tianeptine on circulating neurotransmitters and cardiovascular parameters. Prog Neuropsychopharmacol Biol Psychiatry 2006; 30: 214-22.

[15] Lechin F, van der Dijs B, Baez S, Hernandez-Adrian G, Orozco B, Rodriguez $\mathrm{S}$. The effects of oral arginine on neuroautonomic parameters in healthy subjects. J Appl Res 2006; 6: 201-13.

[16] Lechin F, van der Dijs B, Lechin M. Plasma neurotransmitters and functional illness. Review. Psychother Psychosom 1996; 65: 293318.

[17] Lechin F, van der Dijs B, Lechin AE, et al. Plasma neurotransmitters and cortisol in chronic illness: role of stress. J Med 1994; 25 : 181-192.

[18] Lechin F, van der Dijs B, Pardey-Maldonado B, et al. Circulating neurotransmitter profiles during the different wake-sleep stages in normal subjects. Psychoneuroendocrinology 2004; 29: 669-85.

[19] Lechin F, van der Dijs B, Lechin AE. The autonomic nervous system assessment throughout the wake-sleep cycle \& stress. Psychosom Med 2004; 66: 974-6.

[20] Lechin F, van der Dijs B. Noradrenergic hypothesis of schizophrenia. Prog Neuropsychopharmacol Biol Psychiatry 2005; 29: 777-8.

[21] Lechin F, van der Dijs B. Clonidine therapy for psychosis and tardive dyskinesia. Am. J Psychiatry 1981; 138: 390-1.

[22] Lechin F, van der Dijs B. Noradrenergic or dopaminergic activity in chronic schizophrenia? Br J Psychiatry 1981; 139: 472-3.

[23] Lechin F, van der Dijs B, Gomez F, Lechin E, Oramas O, Villa S. Positive symptoms of acute psychosis: dopaminergic or noradrenergic overactivity? Res Commun Psychol Psychiatry Behav 1983; 8: 23-54.

[24] Lechin F, van der Dijs B. Slow wave sleep (SWS), REM sleep (REMS) and depression. Res Commun Psychol Psychiatry Behav 1984; 9: 227-62.

[25] Lechin F, van der Dijs B. Central nervous system (CNS) circuitry involved in the hyperinsulinism syndrome. Neuroendocrinology 2006; 84: 222-34.

[26] Lechin F, van der Dijs B. Growth hormone, polycystic ovary syndrome and clonidine test. Fertil Steril 2004; 82: 765-7.

[27] Lechin F, van der Dijs B. Intestinal pharmacomanometry and glucose tolerance: evidence for two antagonistic dopaminergic mechanisms in the human. Biol Psychiatry 1981; 16: 969-86.

[28] Lechin F, van der Dijs B. Glucose tolerance, non-nutrient drink and gastrointestinal hormones. Gastroenterology 1981; 80: 216-7.

[29] Lechin F, van der Dijs B. Physiological effects of endogenous CCK on distal colon motility. Acta Gastroenterol Latinoamer 1979; 9 ; 195-203.

[30] Lechin F, Coll-Garcia E, van der Dijs B, Bentolila A, Peña F, Rivas C. The effects of dopaminergic blocking agents on the glucose tolerance test in six humans and six dogs. Experientia 1979; 35: 8867.

[31] Lechin F, Coll-Garcia E, van der Dijs B, Bentolila A, Peña F, Rivas C. Effects of captivity on glucose tolerance in dogs. Experientia 1979; 35: 876-7.

[32] Lechin F, van der Dijs B, Bentolila A, Peña F. The adrenergic influences on the gallbladder emptying. Am J Gastroenterol 1978; 69: 662-8.

[33] Lechin F, van der Dijs B, Orozco B. Gallbladder muscle dysfunction and neuroautonomic disorders. Gastroenterology 2002; 123: $1407-8$.

[34] Lechin F, van der Dijs B, Orozco B. Cholecystokinin (CCK) and secretin and pancreatic secretion of insulin and glucagon. Dig Dis Sci 2002; 47: 2422-3.

[35] Lechin F, van der Dijs B, Insausti CL, et al. Treatment of ulcerative colitis with clonidine. J Clin Pharmacol 1985; 25: 219-26.

[36] Lechin F, van der Dijs B. Treatment of infertility with levodopa. Br Med J 1980; 280, 480.

[37] Lechin F, van der Dijs B, Rada I, et al. Plasma neurotransmitters and cortisol in duodenal ulcer patients: role of stress. Dig Dis Sci 1990; 35(11): 1313-9.

[38] Lechin F, van der Dijs B, Rada I, et al. Recurrent gastroesophageal symptoms and precordial pain in a gastrectomized man improved by amytriptyline. Physiologic, metabolic, endocrine, neurochemical and psychiatric findings. J Med 1989; 20: 407-24.

[39] Lechin F, van der Dijs B, Lechin-Baez S, et al. Two types of irritable bowel syndrome: differences in behavior, clinical signs, distal 
colon motility and hormonal, neurochemical, metabolic, physiological and pharmacological profiles. Arch Ven Farm Clin Terap 1994; 12: 105-14.

[40] Lechin F, van der Dijs B, Bentolila A, Peña F. Antidiarrheal effects of dihydroergotamine. J Clin Pharmacol 1977; 17: 339-349.

[41] Lechin F, van der Dijs B, Bentolila A, Peña F. The spastic colon syndrome. Therapeutic and pathophysiological considerations. J Clin Pharmacol 1977; 17: 431-40.

[42] Lechin F, van der Dijs B. Irritable bowel syndrome, depression and Th-1 autoimmune diseases. Dig Dis Sci 2007; 52: 103-4.

[43] Lechin F, van der Dijs B. Colon motility and psychological traits in the irritable bowel syndrome. Dig Dis Sci 1981; 26: 474.

[44] Lechin F, van der Dijs B, Lechin S, Vitelli G, Lechin ME, Cabrera A. In Velasco M, Ed. Recent advances in Pharmacology and Therapeutics. Amsterdam, Excerpta Medica, 1989, vol 839, pp. 5770.

[45] Lechin F, van der Dijs B, Lechin M, et al. Dramatic improvement with clonidine of acute pancreatitis showing raised catecholamines and cortisol plasma levels: case report of five patients. J Med 23, 339-51.

[46] Lechin F, van der Dijs B, Lechin ME. Neuropharmacological factors, biliary motility and pancreatitis. JOP 2002; 3: 152-4.

[47] Lechin F, van der Dijs B, Azocar J, et al. Definite and sustained with psychoactive drugs of three Crohn's disease patients. III Interamerican Congress of Clinical Pharmacology and Therapeutics and XII Latinoamerican Congress of Pharmacology. Arch Ven Farm Clin Terap 1988; 7(Sup 1): Abst 89.

[48] Lechin F, van der Dijs B, Lechin M, et al. Clonidine treatment of acute pancreatitis: Report of five cases. Acta Gastroenterol Latinoamer 1992; 22: 119-24

[49] Lechin F, van der Dijs B. Central nervous system circuitry and peripheral neural sympathetic activity responsible for essential hypertension. Curr Neurovasc Res 2006; 3: 307-25.

[50] Lechin F, van der Dijs B, Lechin AE. Neural sympathetic activity in essential hypertension. Hypertension 2004; 44: e3-e4.

[51] Lechin F, van der Dijs B, Orozco B, Jahn E, Rodriguez S, Baez S. Neuropharmacological treatment of refractory idiopathic thrombocytopenic purpura: Roles of circulating catecholamines and serotonin. Thromb Haemost 2004; 91: 1254-6.

[52] Lechin F, van der Dijs B, Orozco B, Rodriguez S, Baez S. Neuropharmacological therapy of Polycythemia vera: Roles of circulating catecholamines and serotonin. Thromb Hemost 2005; 93: 175-7.

[53] Lechin F, van der Dijs B, Pardey-Maldonado B, et al. Enhancement of noradrenergic neural transmission: an effective therapy of myasthenia gravis. Report of 52 consecutive patients. J Med 2000; 31: 333-61.

[54] Lechin F, van der Dijs B, Lechin AE. Circulating serotonin, catecholamines and CNS circuitry related to some cardiorespiratory and vascular disorders. J Appl Res 2005; 5: 605-21.

[55] Lechin F, van der Dijs B. Serotonin and pulmonary vasoconstriction. J Appl Physiol 2002; 92: 1363-4.

[56] Lechin F, Lechin ME, van der Dijs B. Plasma catecholamines and chronic congestive heart failure. Circulation 2002; 106: 222.

[57] Lechin F, van der Dijs B, Lechin AE. Pulmonary hypertension left ventricular dysfunction and plasma serotonin. $\mathrm{Br} \mathrm{J}$ Pharmacol 2002;1 37(6): 937-8.

[58] Lechin F, van der Dijs B, Lechin AE. Plasma serotonin, pulmonary hypertension and bronchial asthma. Clin Sci 2002; 103: 345-6.

[59] Lechin F, van der Dijs B, Lechin AE. Tianeptine, plasma serotonin and pulmonary hypertension. Lancet 2003; 361(9351): 87.

[60] Lechin F, van der Dijs B, Orozco B, Rodriguez S, Baez S. Elective stenting, platelet serotonin and thrombotic events. Platelets 2004; 15: 462 .

[61] Lechin F, van der Dijs B, Orozco B, et al. The serotonin uptakeenhancing drug tianeptine suppresses asthmatic symptoms in children. A double-blind crossover placebo-controlled study. J Clin Pharmacol 1998; 38: 918-25.

[62] Lechin F, van der Dijs B, Orozco B, et al. Neuropharmacological treatment of bronchial asthma with an antidepressant drug: tianeptine. A double-blind crossover placebo-controlled study. Clin Pharmacol Ther 1998; 64: 223-32.

[63] Lechin F, van der Dijs B, Orozco B, Lechin ME, Lechin AE. Increased levels of free-serotonin in plasma of symptomatic asthmatic patients. Ann Allergy Asthma Immunol 1996; 77: 245-53.
[64] Lechin F, van der Dijs B, Lechin AE. Treatment of bronchial asthma with tianeptine. Methods Find Exp Clin Pharmacol 2004; 26: 697-701.

[65] Lechin F, van der Dijs B, Lechin ME. Neurocircuitry and Neuroautonomic Disorders. Reviews and Therapeutic Strategies. Basel: Karger 2002

[66] Lechin F, van der Dijs B, Lechin ME, et al.. Pimozide therapy for trigeminal neuralgia. Arch Neurol 1989; 46: 960-3.

[67] Lechin F, van der Dijs B. In: Maiese K, Ed. Neurovascular medicine: Pursuing cellular longevity for healthy aging. New York, Oxford University Press, 2008. (In Press).

[68] Lechin F, van der Dijs B, Lechin AE. Natural killer cells activity and neuroimmunological treatment of cancer. Clin Cancer Res 2004; 10:8 120-1.

[69] Lechin F, van der Dijs B, Azocar J, et al. Stress, immunology and cancer: effect of psychoactive drugs. Arch Ven Farm Clin Terap 1987; 6: 28-43

[70] Maiorov DN, Wilton ER, Badoer E, Petrie D, Head GA, Malpas SC. Sympathetic response to stimulation of the pontine A5 region in conscious rabbits. Brain Res 1999; 815: 227-36.

[71] Drye RG, Baisden RH, Whittington DL, Woodruff ML. The effects of stimulation of the A5 region on blood pressure and heart rate in rabbits. Brain Res Bull. 1990; 24: 33-9.

[72] Loewy AD, Gregorie EM, McKellar S, Baker RP. Electrophysiological evidence that the A5 catecholamine cell group is a vasomotor center. Brain Res 1979; 178: 196-200.

[73] Li YW, Wesselingh SL, Blessing WW. Projections from rabbit caudal medulla to $\mathrm{C} 1$ and A5 sympathetic premotor neurons, demonstrated with phaseolus leucoagglutinin and herpes simplex virus J Comp Neurol 1992; 317: 379-95.

[74] Byrum CE, Stornetta R, Guyenet PG. Electrophysiological properties of spinally-projecting A5 noradrenergic neurons. Brain Res 1984; 303: 15-29.

[75] Loewy AD. Descending pathways to the sympathetic preganglionic neurons. Prog Brain Res 1982; 57: 267-77.

[76] Dampney RA. Functional organization of central pathways regulating the cardiovascular system. Physiol Rev 1994; 74: 323-64.

[77] Kvetnansky R, Bodnar I, Shahar T, Uhereczky G, Krizanova O, Mravec B. Effect of lesion of A5 and A7 brainstem noradrenergic areas or transection of brainstem pathways on sympathoadrenal activity in rats during immobilization stress. Neurochem Res 2006; 31: 267-75.

[78] Jansen AS, Van Nguyen X, Karpitskiy V, Mettenleiter TC, Loewy AD. Central command neurons of the sympathetic nervous system: basis of the fight-or-flight response. Science 1995; 270: 644-6.

[79] Sourkes TL. Neurotransmitters and central regulation of adrenal functions. Review. Biol Psychiatry 1985; 20: 182-91.

[80] Andrade R, Aghajanian GK. Single cell activity in the noradrenergic A-5 region: responses to drugs and peripheral manipulations of blood pressure. Brain Res 1982; 242: 125-35.

[81] Gonzalez-Rubio JM, Garcia de Diego AM, Egea J, et al. Blockade of nicotinic receptors of bovine adrenal chromaffin cells by nanomolar concentrations of atropine. Eur J Pharmacol 2006; 535: 13 24.

[82] Fenik V, Marchenko V, Janssen P, Davies RO, Kubin L. A5 cells are silenced when REM sleep-like signs are elicited by pontine carbachol. J Appl Physiol 2002; 93: 1448-56.

[83] Liu JP, Clarke IJ, Funder JW, Engler D. Evidence that the central noradrenergic and adrenergic pathways activate the hypothalamicpituitary-adrenal axis in the sheep. Endocrinology 1991; 129: 2009.

[84] Drew GM. Effects of alpha-adrenoceptor agonists and antagonists on pre- and postsynaptically located alpha-adrenoceptors. Eur J Pharmacol 1976; 36: 313-20.

[85] Young JB, Rosa RM, Landsberg L. Dissociation of sympathetic nervous system and adrenal medullary responses. Am J Physiol 1984; 247: E35-E40.

[86] Robertson D, Johnson GA, Robertson RM, Nies AS, Shand DG, Oates JA. Comparative assessment of stimuli that release neuronal and adrenomedullary catecholamines in man. Circulation 1979; 59 637-43.

[87] Elenkov IJ, Wilder RL, Chrousos GP, Vizi ES. The sympathetic nerve--an integrative interface between two supersystems: the brain and the immune system. Pharmacol Rev 2000; 52: 595-638

[88] Pieribone VA, Aston-Jones G. Adrenergic innervation of the rat nucleus locus coeruleus arises predominantly from the $\mathrm{C} 1$ adrener- 
gic cell group in the rostral medulla. Neuroscience 1991; 41: 52542.

[89] Ennis M, Aston-Jones G. Two physiologically distinct populations of neurons in the ventrolateral medulla innervate the locus coeruleus. Brain Res 1987; 425: 275-82.

[90] Barbeito L, Fernandez C, Silveira R, Dajas F. Evidences of a sympatho-adrenal dysfunction after lesion of the central noradrenergic pathways in rats. J Neural Transm 1986; 67: 205-14.

[91] Granata AR, Numao Y, Kumada M, Reis DJ. A1 noradrenergic neurons tonically inhibit sympathoexcitatory neurons of $\mathrm{C} 1$ area in rat brainstem. Brain Res 1986; 377: 127-46.

[92] Kostowski W. Two noradrenergic systems in the brain and their interactions with other monoaminergic neurons. Review. Pol J Pharmacol Pharm 1979; 31: 425-36.

[93] Speciale SG, Crowley WR, O'Donohue TL, Jacobowitz DM. Forebrain catecholamine projections of the A5 cell group. Brain Res 1978;154:128-33.

[94] Bongiovanni R, Kirkbride B, Walmire P, Jaskiw GE. Tyrosine administration does not affect desipramine-induced dopamine levels as measured in vivo in prefrontal cortex. Brain Res 2005; 1054 : 203-6.

[95] Biegon A, Rainbow TC. Localization and characterization of $[3 \mathrm{H}]$ desmethylimipramine binding sites in rat brain by quantitative autoradiography. J Neurosci 1983; 3(5): 1069-76.

[96] Elam M, Thoren P, Svensson TH. Locus coeruleus and sympathetic nerves: activation by visceral afferents. Brain Res 1986; 375: 11725.

[97] Zhou CJ, Zou X, Ku YH. Central neural mechanism underlying pressor response to excitation of locus coeruleus in rats. Sheng $\mathrm{Li}$ Xue Bao 1991; 43: 556-64.

[98] Svensson TH, Thoren P. Brain noradrenergic neurons in the locus coeruleus: inhibition by blood volume load through vagal afferents. Brain Res 1979; 172: 174-8.

[99] Grzanna R, Chee WK, Akeyson EW. Noradrenergic projections to brainstem nuclei: evidence for differential projections from noradrenergic subgroups. J Comp Neurol 1987; 263: 76-91.

[100] Guo H, Hellard DT, Huang L, Katz DM. Development of pontine noradrenergic A5 neurons requires brain-derived neurotrophic factor. Eur J Neurosci 2005; 21: 2019-23.

[101 Jackson VM, Cunnane TC. Neurotransmitter release mechanisms in sympathetic neurons: past, present, and future perspectives. Review. Neurochem Res 2001; 26: 875-89.

[102] Tassin JP. NE/DA interactions in prefrontal cortex and their possible roles as neuromodulators in schizophrenia. Review. J Neural Transm Suppl 1992; 36: 135-62.

[103] Levitt P, Moore RY. Origin and organization of brainstem catecholamine innervation in the rat. J Comp Neurol 1979; 186: 505-28.

[104] Grudzien A, Shaw P, Weintraub S, Bigio E, Mash DC, Mesulam MM. Locus coeruleus neurofibrillary degeneration in aging, mild cognitive impairment and early Alzheimer's disease. Neurobiol Aging 2007; 28: 327-35.

[105] Spencer T, Biederman J, Coffey B, et al. A double-blind comparison of desipramine and placebo in children and adolescents with chronic tic disorder and comorbid attention-deficit/hyperactivity disorder. Arch Gen Psychiatry 2002; 59: 649-56.

[106] Devoto P, Flore G, Pani L, Gessa GL. Evidence for co-release of noradrenaline and dopamine from noradrenergic neurons in the cerebral cortex. Mol Psychiatry 2001; 6: 657-64.

[107] Ishida Y, Shirokawa T, Miyaishi O, Komatsu Y, Isobe K. Agedependent changes in projections from locus coeruleus to hippocampus dentate gyrus and frontal cortex. Eur J Neurosci 2000; 12 : 1263-70.

[108] Seals DR, Esler MD. Human ageing and the sympathoadrenal system. J Physiol 2000; 528: 407-17.

[109] Cohen RZ, Seeman MV, Gotowiec A, Kopala L. Earlier puberty as a predictor of later onset of schizophrenia in women. Am J Psychiatry $1999 ; 156(7)$ : 1059-64.

[110] Knable MB, Hyde TM, Murray AM, Herman MM, Kleinman JE. A postmortem study of frontal cortical dopamine D1 receptors in schizophrenics, psychiatric controls, and normal controls. Biol Psychiatry 1996;40:1191-1199.

[111] Florin-Lechner SM, Druhan JP, Aston-Jones G, Valentino RJ. Enhanced norepinephrine release in prefrontal cortex with burst stimulation of the locus coeruleus. Brain Res 1996; 742: 89-97.

[112] Pozzi L, Invernizzi R, Cervo L, Vallebuona F, Samanin R. Evidence that extracellular concentrations of dopamine are regulated by noradrenergic neurons in the frontal cortex of rats. J Neurochem 1994; 63: 195-200.

[113] DeLisi LE, Bass N, Boccio A, Shields G, Morganti C. Age of onset in familial schizophrenia. Arch Gen Psychiatry 1994; 51: 334-335.

[114] Sawchenko PE, Swanson LW. The organization of noradrenergic pathways from the brainstem to the paraventricular and supraoptic nuclei in the rat. Brain Res 1982; 257: 275-325.

[115] Craven RM, Priddle TH, Crow TJ, Esiri MM. The locus coeruleus in schizophrenia: a postmortem study of noradrenergic neurones. Neuropathol Appl Neurobiol 2005; 31: 115-26.

[116] Southwick SM, Krystal JH, Morgan CA, et al. Abnormal noradrenergic function in posttraumatic stress disorder. Arch Gen Psychiatry 1993; 50: 266-74.

[117] Roy A, Pickar D, Linnoila M, Potter WZ. Plasma norepinephrine level in affective disorders. Relationship to melancholia. Arch Gen Psychiatry $1985 ; 42: 1181-5$.

[118] Murburg MM, McFall ME, Lewis N, Veith RC. Plasma norepinephrine kinetics in patients with posttraumatic stress disorder. Biol Psychiatry 1995; 38: 819-25.

[119] Kinzie JD, Leung P. Clonidine in Cambodian patients with posttraumatic stress disorder. J Nerv Ment Dis 1989; 177: 546-50.

[120] Haglund M, Sjöbeck M, Englund E. Locus ceruleus degeneration is ubiquitous in Alzheimer's disease: Possible implications for diagnosis and treatment. Neuropathology 2006; 26: 528-32.

[121] Sved AF, Cano G, Card JP. Neuroanatomical specificity of the circuits controlling sympathetic outflow to different targets. Review. Clin Exp Pharmacol Physiol 2001; 28: 115-9.

[122] Mouton PR, Pakkenberg B, Gundersen HJ, Price DL. Absolute number and size of pigmented locus coeruleus neurons in young and aged individuals. J Chem Neuroanat 1994; 7: 185-90.

[123] Vitiello B, Veith RC, Molchan SE, et al. Autonomic dysfunction in patients with dementia of the Alzheimer type. Biol Psychiatry 1993; 34: 428-33.

[124] Kalin NH, Dawson G, Tariot P, et al. Function of the adrenal cortex in patients with major depression. Psychiatry Res 1987; 22: 117-25.

[125] Rausch JL, Janowsky DS, Risch SC, Huey LY. Physostigmine effects on serotonin uptake in human blood platelets. Eur J Pharmacol 1985; 109: 91-6.

[126] Grundy D. Serotonin and sensory signalling from the gastrointestinal lumen. J Physiol 2006; 575: 1-2.

[127] Lomholt M, Nedergaard OA. Prejunctional muscarinic receptor modulation of noradrenaline release from sympathetic neurones in rabbit aorta. Pharmacol Toxicol 2000; 86: 264-9.

[128] Lou YP, Franco-Cereceda A, Lundberg JM. Variable alpha-2 adrenoceptor-mediated inhibition of bronchoconstriction and peptide release upon activation of pulmonary afferents. Eur J Pharmacol 1992; 210: 173-81.

[129] Snider RM, Gerald MC. Noradrenergic-mediated potentiation of acetylcholine release from the phrenic nerve: Evidence for presynaptic alpha 1-adrenoceptor involvement. Life Sci 1982; 31: 853-7.

[130] Dupont LJ, Pype JL, Demedts MG, De Leyn P, Deneffe G, Verleden GM. The effects of 5-HT on cholinergic contraction in human airways in vitro. Eur Respir J 1999; 14: 642-9.

[131] Schworer H, Racke K, Kilbinger H. Cholinergic modulation of the release of 5-hydroxytryptamine from the guinea pig ileum. Naunyn-Schmiedeberg's Arch Pharmacol 1987; 336: 127-32.

[132] Lechin F, van der Dijs B. Neuropharmacological therapy of carcinoid syndrome. Neuroendocrinology 2005; 81: 137-8.

[133] Lechin F, van der Dijs B, Orozco B, Rodriguez S, Baez S. Neuropharmacological therapy of the neuroendocrine carcinoid syndrome: Report of two cases. J Appl Res 2005; 5: 109-14.

[134] Holst JJ, Schaffalitzky de Muckadell OB, Fahrenkrug J. Nervous control of pancreatic exocrine secretion in pigs. Acta Physiol Scand 1979; 105: 33-51.

[135] Hong SS, Mage, DF. Pharmacological studies on the regulation of pancreatic secretion in pigs. Ann Surg 1970; 172: 41-8.

[136] Lechin F, van der Dijs B, Hernandez-Adrian G. Dorsal Raphe (DR) vs. Median Raphe (MR) serotonergic antagonism. Anatomical, physiological, behavioral, neuroendocrinological, neuropharmacological and clinical evidences: Relevance for neuropharmacological therapy. Review. Prog Neuro-Psychopharmacol Biol Psychiatry 2006; 30: 565-85.

[137] Lechin F, van der Dijs B, Orozco B, Hernandez-Adrian G, Rodriguez $\mathrm{S}$, Baez S. Similar autonomic nervous system disorders underlying cystic fibrosis and pancreatic cysts allowed common neuro- 
pharmacological therapy: Report of four cases. J Appl Res 2005; 5: 299-304.

[138] Lechin F, van der Dijs B. In Velasco M, Ed. Clinical Pharmacology and Therapeutics. Amsterdam, Excerpta Medica, vol 604, 1982; pp. 166-73.

[139] Rudorfer MV, Young RC. Anticholinergic effects and plasma desipramine levels. Clin Pharmacol Ther 1980; 28: 703-6.

[140] Lechin F, van der Dijs B, Amat J, Lechin S. In Lechin F, van der Dijs B, Eds. Neurochemistry and Clinical Disorders: Circuitry of some psychiatric and psychosomatic syndromes. Boca Raton, FL, CRC Press, 1989, pp. 50-64.

[141] Lechin F, van der Dijs B, Lechin E. The Autonomic Nervous System: Physiological basis of psychosomatic therapy. Barcelona, Spain: Editorial Cientifico-Medica 1979.

[142] Buccafusco JJ, Magri V. Modification of spino-bulbar autonomic cholinergic systems by activation of alpha-adrenergic receptors. J Auton Nerv Syst 1989; 28: 133-40.

[143] O’Donovan D, Feinle C, Tonkin A, Hoorowitz M, Jones KL. Postprandial hypotension in response to duodenal glucose delivery in healthy older subjects. J Physiol 2002; 540: 673-9.

[144] Bagdy G, Calogero AE, Murphy DL, Szemeredi K. Serotonin agonists cause parallel activation of the sympathoadrenomedullary system and the hypothalamo-pituitary-adrenocortical axis in conscious rats. Endocrinology 1989; 125(5): 2664-9.

[145] Urbanski RW, Sapru HN. Evidence for a sympathoexcitatory pathway from the nucleus tractus solitarii to the ventrolateral medullary pressor area. J Auton Nerv Syst 1988; 23: 161-74.

[146] Byrum CE, Guyenet PG. Afferent and efferent connections of the A5 noradrenergic cell group in the rat. J Comp Neurol 1987; 261: 529-42.

[147] Astier B, Kitahama K, Denoroy L, Berod A, Jouvet M, Renaud B. Biochemical evidence for an interaction between adrenaline and noradrenaline neurons in the rat brainstem. Brain Res 1986; 397: 333-40.

[148] Lechin F, van der Dijs B, Benaim M. Stress versus depression. Review. Prog Neuro-Psychopharmacol Biol Psychiatry 1996; 20: 899-950.

[149] Rudorfer MV, Sherer MA, Lane EA, Golden RN, Linnoila M, Potter WZ. Acute noradrenergic effects of desipramine in depression. J Clin Psychopharmacol 1991; 11: 22-7.

[150] Cutler NR, Zavadil AP 3rd, Linnoila M, Scheinin M, Rudorfer MV, Potter WZ. Effects of chronic desipramine on plasma norepinephrine concentrations and cardiovascular parameters in elderly depressed women: a preliminary report. Biol Psychiatry 1984; 19: 549-56.

[151] Lechin F, van der Dijs B, Pardey-Maldonado B, et al. Effects of desipramine on circulating neurotransmitters in patients affected by neural sympathetic or adrenal sympathetic hyperactivity. J Appl Res 2008; 2: 151-67.

[152] D'Aquila PS, Peana AT, Carboni V, Serra G. Exploratory behaviour and grooming after repeated restraint and chronic mild stress: effect of desipramine. Eur J Pharmacol 2000; 399: 43-7.

[153] Langer SZ, Angel I. Pre- and postsynaptic alpha-2 adrenoceptors as target for drug discovery. J Neural Transm Suppl 1991; 34: 171-7.

[154] Mignot E, Laude D, Elghozi JL, Le Quan-Bui KH, Meyer P. Central administration of yohimbine increases free 3-methoxy-4hydroxyphenylglycol in the cerebrospinal fluid of the rat. Eur $\mathbf{J}$ Pharmacol 1982; 83: 135-8.

[155] Ohliger-Frerking P, Horowitz JM, Horwitz BA. Enhanced adrenergic excitation of serotonergic dorsal raphe neurons in genetically obese rats. Neurosci Lett 2002; 332: 107-10.

[156] Peyron C, Luppi PH, Fort P, Rampon C, Jouvet M. Lower brainstem catecholamine afferents to the rat dorsal raphe nucleus. J Comp Neurol 1996; 364: 402-13.

[157] Korte SM, Van Duin S, Bouws GA, Koolhaas JM, Bohus B. Involvement of hypothalamic serotonin in activation of the sympathoadrenomedullary system and hypothalamo-pituitaryadrenocortical axis in male Wistar rats. Eur J Pharmacol 1991; 197: 225-8.

[158] Tibirica E, Mermet C, Feldman J, Gonon F, Bousquet P. Correlation between the inhibitory effect on catecholaminergic ventrolateral medullary neurons and the hypotension evoked by clonidine: a voltammetric approach. J Pharmacol Exp Ther 1989; 250: 642-7.

[159] Valentino RJ, Martin DL, Suzuki M. Dissociation of locus coeruleus activity and blood pressure. Effects of clonidine and corticotropin-releasing factor. Neuropharmacology 1986; 25: 603-10.
[160] Aston-Jones G, Shipley MT, Chouvet G, et al. Afferent regulation of locus coeruleus neurons: anatomy, physiology and pharmacology. Review. Prog Brain Res 1991; 88: 47-75.

[161] Kawano S, Osaka T, Kannan H, Yamashita H. Excitation of hypothalamic paraventricular neurons by stimulation of the raphe nuclei. Brain Res Bull 1992; 28: 573-9.

[162] Liposits Z, Phelix C, Paull WK. Synaptic interaction of serotonergic axons and corticotropin releasing factor (CRF) synthesizing neurons in the hypothalamic paraventricular nucleus of the rat. A light and electron microscopic immunocytochemical study. Histochemistry 1987; 86: 541-9.

[163] Gamallo A, Villanua A, Trancho G, Fraile A. Stress adaptation and adrenal activity in isolated and crowded rats. Physiol Behav 1986; 36: 217-21.

[164] Gauthier P. Pressor responses and adrenomedullary catecholamines release during brain stimulation in the rat. Can J Physiol Pharmacol 1981; 59: 485-92.

[165] Sastry KS, Karpova Y, Prokopovich S, et al. Epinephrine protects cancer cells from apoptosis via activation of camp-dependent protein kinase and bad phosphorylation. J Biol Chem 2007; 282: 14094-100.

[166] Lechin F, van der Dijs B, Vitelli G, et al. Psychoneuroendocrinological and immunological parameters in cancer patients: involvement of stress and depression. Psychoneuroendocrinology 1990; 15: 435-51.

[167] Lechin F, van der Dijs B, Azocar J, et al. Neurochemical and inmunological profiles of three clinical stages in 50 advanced cancer patients. III Interamerican Congress of Clinical Pharmacology and Therapeutics and XII Latinoamerican Congress of Pharmacology. Arch Ven Farm Clin Terap 1988; 7(Sup 1): Abst 39.

[168] Lechin S, Vitelli G, Martinez C, et al. Plasma neurotransmitters, lymphocite subpopulations and natural killer cell activity in terminal cancer patients. III Interamerican Congress of Clinical Pharmacology and Therapeutics and XII Latinoamerican Congress of Pharmacology. Arch Ven Farm Clin Terap 1988; 7(Sup 1): Abst 37.

[169] Maling TJ, Dollery CT, Hamilton CA. Clonidine and sympathetic activity during sleep. Clin Sci 1979; 57: 509-14.

[170] Sved AF, Felsten G. Stimulation of the locus coeruleus decreases arterial pressure. Brain Res 1987; 414: 119-32.

[171] Siever LJ, Uhde TW, Jimerson DC, et al. Differential inhibitory noradrenergic responses to clonidine in 25 depressed patients and 25 normal control subjects. Am J Psychiatry 1984; 141: 733-41.

[172] Siever LJ, Uhde TW. New studies and perspectives on the noradrenergic receptor system in depression: effects of the alpha 2adrenergic agonist clonidine. Biol Psychiatry 1984; 19: 131-56.

[173] Iversen LL. Role of transmitter uptake mechanisms in synaptic neurotransmission. Br J Pharmacol 2000; 131: 61-81.

[174] van Diest R, Appels WP. Sleep physiological characteristics of exhausted men. Psychosom Med 1994; 56: 28-35.

[175] McCarley RW. REM sleep and depression: common neurobiological control mechanisms. Am J Psychiatry 1982; 139: 565-70.

[176] Reis DJ, Ruggiero DA, Morrison SF. The C1 area of the rostralventrolateral medulla oblongata. A critical brainstem region for control of resting and reflex integration of arterial pressure. Review. Am J Hypertens 1989; 2: 363S-74S.

[177] Groves DA, Bowman EM, Brown VJ. Recordings from the rat locus coeruleus during acute vagal nerve stimulation in the anaesthetised rat. Neurosci Lett 2005; 379: 174-9.

[178] Eisenhofer G, Kopin IJ, Goldstein DS. Catecholamine metabolism: a contemporary view with implications for physiology and medicine. Review. Pharmacol Rev 2004; 56: 331-49.

[179] Aulakh CS, Mazzola-Pomietto P, Murphy DL. Long-term antidepressant treatment restores clonidine's effect on growth hormone secretion in a genetic animal model of depression. Pharmacol Biochem Behav 1996; 55: 265-8.

[180] Atkinson J, Boillat N, Dennis T, Langer SZ, Scatton B. Effect of prolonged clonidine treatment and its withdrawal on noradrenaline turnover in the cerebral cortex and medulla oblongata of the spontaneously hypertensive rat. Naunyn Schmiedeberg's Arch Pharmacol 1987; 336: 77-80.

[181] Bond WS. Psychiatric indications for clonidine: the neuropharmacologic and clinical basis. J Clin Psychopharmacol 1986; 6: 81-7.

[182] Szabo B, Schultheiss A. Desipramine inhibits sympathetic nerve activity in the rabbit. Naunyn Schmiedebergs Arch Pharmacol 1990; 342: 469-76. 
[183] O'Driscoll DM, Morrell MJ. The interaction between respiratory and autonomic function during sleep-related changes in pharyngeal airway patency. Review. Auton Neurosci 2005; 120: 18-25.

[184] Weiss JW, Liu MD, Huang J. Physiological basis for a causal relationship of obstructive sleep apnoea to hypertension. Review. Exp Physiol 2007; 92: 21-6.

[185] Rowley JA, Sanders CS, Zahn BR, Badr MS. Effect of REM sleep on retroglossal cross-sectional area and compliance in normal subjects. J Appl Physiol 2001; 91: 239-48.

[186] Hilaire G, Monteau R, Errchidi S. Possible modulation of the medullary respiratory rhythm generator by the noradrenergic A5 area: an in vitro study in the newborn rat. Brain Res 1989; 485: 325-32.

[187] Rukhadze I, Kubin L. Differential pontomedullary catecholaminergic projections to hypoglossal motor nucleus and viscerosensory nucleus of the solitary tract. J Chem Neuroanat 2007; 33: 23-33.

[188] Engeland WC. Functional innervation of the adrenal cortex by the splanchnic nerve. Review. Horm Metab Res 1998; 30: 311-4.

[189] Lokhandwala MF, Jandhyala BS. The role of sympathetic nervous system in the vascular actions of dopamine. J Pharmacol Exp Ther 1979; 210: 120-6.

[190] Porta S, Emsenhuber W, Felsner P, Schauenstein K, Supanz S. Norepinephrine triggers medullar epinephrine depletion during normoglycemia. Life Sci 1989; 45(19): 1763-9.

[191] Szabo B, Hedler L, Starke K. Peripheral presynaptic and central effects of clonidine, yohimbine and rauwolscine on the sympathetic nervous system in rabbits. Naunyn Schmiedebergs Arch Pharmacol 1989; 340: 648-57.

[192] Grundstrom N, Andersson RG, Wikberg JE. Prejunctional alpha 2 adrenoceptors inhibit contraction of tracheal smooth muscle by inhibiting cholinergic neurotransmission. Life Sci 1981; 28(26): 2981-6.
[193] Punnen S, Willette RN, Krieger AJ, Sapru HN. Medullary pressor area: site of action of intravenous physostigmine. Brain Res 1986; 382: $178-84$

[194] Minson CT, Wladkowski SL, Pawelczyk JA, Kenney WL. Age, splanchnic vasoconstriction, and heat stress during tilting. Am J Physiol 1999; 276: R203-12.

[195] Perego C, Vetrugno GC, De Simoni MG, Algeri S. Aging prolongs the stress-induced release of noradrenaline in rat hypothalamus. Neurosci Lett 1993; 157: 127-30.

[196] Bialik RJ, Smythe JW, Sardelis M, Roberts DC. Adrenal demedullation blocks and brain norepinephrine depletion potentiates the hyperglycemic response to a variety of stressors. Brain Res 1989; 502: 88-98.

[197] Barnes RF, Raskind M, Gumbrecht G, Halter JB. The effects of age on the plasma catecholamine response to mental stress in man. J Clin Endocrinol Metab 1982; 54: 64-9.

[198] Rubin PC, Scott PJ, McLean K, Reid JL. Noradrenaline release and clearance in relation to age and blood pressure in man. Eur J Clin Invest 1982; 12: 121-5.

[199] Chan-Palay V, Asan E. Alterations in catecholamine neurons of the locus coeruleus in senile dementia of the Alzheimer type and in Parkinson's disease with and without dementia and depression. J Comp Neurol 1989; 287: 373-92.

[200] Chan-Palay V, Asan E. Quantitation of catecholamine neurons in the locus coeruleus in human brains of normal young and older adults and in depression. J Comp Neurol 1989; 287: 357-72.

[201] Lohr JB, Jeste DV. Locus ceruleus morphometry in aging and schizophrenia. Review. Acta Psychiatr Scand 1988; 77: 689-97.

Received: April 24, 2008

Revised: September 26, 2008

Accepted: September 26, 2008

(C) Lechin and van der Dijs; Licensee Bentham Open

This is an open access article licensed under the terms of the Creative Commons Attribution Non-Commercial License (http://creativecommons.org/licenses/by-nc/3.0/) which permits unrestricted, non-commercial use, distribution and reproduction in any medium, provided the work is properly cited. 